\title{
New York Heart Association Class III
}

National Cancer Institute

\section{Source}

National Cancer Institute. New York Heart Association Class III. NCI Thesaurus. Code C66907.

A finding associated with a patient with defined or presumed cardiac disease with marked limitation of physical activity. They are comfortable at rest. Less than ordinary activity causes fatigue, palpitation, or dyspnea. (from The Criteria Committee of the New York Heart Association. Nomenclature and Criteria for Diagnosis of Diseases of the Heart and Great Vessels. 9th ed. Boston, Mass: Little, Brown \& Co; 1994:253-256.) 